\title{
Enhanced Osseointegration of Titanium Implants by Surface Modification with Silicon-doped Titania Nanotubes
}

This article was published in the following Dove Press journal: International Journal of Nanomedicine

\author{
Xijiang Zhao',* \\ Linna You',* \\ Tao Wang' \\ Xianjun Zhang' \\ Zexi $\mathrm{Li}^{2}$ \\ Luguang Ding ${ }^{2}$ \\ Jiaying $\mathrm{Li}^{2}$ \\ Can Xiao ${ }^{2}$ \\ Fengxuan $\mathrm{Han}^{2}$ \\ Bin $\mathrm{Li}^{2}{ }^{2}$ \\ 'Department of Orthopedics, The \\ Affiliated Hospital of Jiangnan University, \\ Wuxi, Jiangsu 214062, People's Republic \\ of China; ${ }^{2}$ Departments of Orthopaedic \\ Surgery and Stomatology, The First \\ Affiliated Hospital, Orthopaedic Institute, \\ Soochow University, Suzhou, Jiangsu \\ 215006, People's Republic of China
}

*These authors contributed equally to this work
Correspondence: Bin $\mathrm{Li}$

Soochow University (South Campus), 708 Renmin Road, Rm 308 Bldg I, Suzhou, Jiangsu 215007, People's Republic of China $\mathrm{Tel} / \mathrm{Fax}(+86)$ 5 | 2-6778-I I 63

Email binli@suda.edu.cn

Can Xiao

The First Affiliated Hospital of Soochow University, 188 Shizi Street, Suzhou, Jiangsu 215006, People's Republic of China

Email canxiao05II@I63.com
Introduction: Despite great progress made in developing orthopedic implants, the development of titanium (Ti) implants with ideal early osseointegration remains a big challenge. Our pilot study has demonstrated that $\mathrm{Si}-\mathrm{TiO}_{2}$ nanotubes on the surface of Ti substrates could enhance their osteogenic activity. Hence, in this study, we aim to comprehensively evaluate the effects of silicon-doped titania $\left(\mathrm{Si}-\mathrm{TiO}_{2}\right)$ nanotubes on the osseointegration property of $\mathrm{Ti}$ implants.

Materials and Methods: The Ti implants were surface modified with $\mathrm{Si}_{-} \mathrm{TiO}_{2}$ nanotubes through in situ anodization and Si plasma immersion ion implantation (PIII) method. Three groups were divided as $\mathrm{Ti}$ implants $(\mathrm{Ti})$, Ti modified with $\mathrm{TiO}_{2}$ nanotubes $\left(\mathrm{TiO}_{2}-\mathrm{NTs}\right)$ and $\mathrm{Ti}$ modified with $\mathrm{Si}-\mathrm{TiO}_{2}$ nanotubes $\left(\mathrm{Si}-\mathrm{TiO}_{2}-\mathrm{NTs}\right)$. The morphology of $\mathrm{Si}_{-} \mathrm{TiO}_{2}$ nanotubes was observed by scanning electron microscope. The growth and osteogenic differentiation of MC3T3-E1 cells on the Ti implants were evaluated. Further, the pull-out tests and in vivo osseointegration ability evaluation were performed after implanting the screws in the femur of Sprague Dawley rats.

Results: The $\mathrm{Si}-\mathrm{TiO}_{2}$ nanotubes could be seen on the surface of Ti implants. The MC3T3-E1 cells could grow on the surface of $\mathrm{Ti}, \mathrm{TiO}_{2}-\mathrm{NTs}$ and $\mathrm{Si}-\mathrm{TiO}_{2}-\mathrm{NTs}$, and showed fast proliferation rate on the $\mathrm{Si}-\mathrm{TiO}_{2}-\mathrm{NTs}$. Moreover, the production of some osteogenesis-related proteins (ALP and Runx2) at one week and calcium deposition at four week was also enhanced in $\mathrm{Si}_{-} \mathrm{TiO}_{2}-\mathrm{NTs}$ rather than other groups. In vivo osseointegration results showed that $\mathrm{Si}-\mathrm{TiO}_{2}$ nanotube-modified $\mathrm{Ti}$ screws had higher pullout force at two and four weeks as well as enhanced new bone formation at six weeks compared to bare Ti screws and Ti screws modified with $\mathrm{TiO}_{2}$ nanotubes alone.

Discussion: The modification of $\mathrm{Si}_{-} \mathrm{TiO}_{2}-\mathrm{NTs}$ on the Ti substrate could generate a nanostructured and hydrophilic surface, which can promote cell growth. Moreover, the existence of the $\mathrm{TiO}_{2}$ nanotubes and $\mathrm{Si}$ element also can improve the in vitro osteogenic differentiation of MC3T3-E1 cells and early bone formation around the implanted screws. Together, findings from this study show that surface modification of $\mathrm{Ti}$ implants with $\mathrm{Si}^{-\mathrm{TiO}_{2}}$ nanotubes could enhance early osseointegration and therefore has the potential for clinical applications.

Keywords: osseointegration, implant, silicon, titanium dioxide, nanotubes

\section{Introduction}

Titanium (Ti) has been widely used in hard tissue repair such as hip and knee joints due to the high mechanical properties and good biocompatibility. ${ }^{1}$ However, in some clinical applications, it is important to achieve faster peri-implant healing. It is believed that optimizing the surface properties of implants can facilitate the adhesion of bone-forming cells and thereby promote early osseointegration. ${ }^{2-4}$ 
Generally, a thin $(2-5 \mathrm{~nm})$ film of titania, or titanium dioxide $\left(\mathrm{TiO}_{2}\right)$, forms on the surface of titanium implant, which can protect the titanium substrate from corrosion when it is exposed to air. ${ }^{5}$ However, such a $\mathrm{TiO}_{2}$ layer does not effectively recruit cells to facilitate bone formation. ${ }^{6}$ Therefore, a variety of surface modification techniques including anodization have been used to improve osseointegration. ${ }^{7,8}$ For example, well-organized topographic cues at nano/microscales could improve biocompatibility and promote bone formation, which are crucial for successful osseointegration between implant and bone. ${ }^{9,10}$ Thus, implants modified with nano-/micro-structured surface, being capable of regulating cell behaviors, are very promising for orthopedic applications. ${ }^{11}$ For example, the filopodia of cells can go into the pore of nanotubes to form a locked-in cell structure for bone ingrowth. ${ }^{12}$

In addition, surface chemistry is another aspect to influence the cell/tissue-material interactions. ${ }^{13}$ In a recent study, the surface of a clustered $\mathrm{TiO}_{2}$ nanotubular structure, fabricated by anodization, was further modified with platelet derived growth factor-BB (PDGF-BB) to enhance expression of osteogenesis-related genes of bone marrow mesenchymal stem cells (BM-MSCs). ${ }^{14}$ The incorporation of bioactive elements such as silicon ( $\mathrm{Si}$ ) was conducted to improve the biological performances of biomaterials. The element of Si has been reported to accelerate bone mineralization and enhance the proliferation, differentiation and collagen production of osteoblasts. ${ }^{15-17}$ Therefore, Siincorporated biomaterials including hydroxyapatite, ${ }^{18,19}$ tricalcium phosphate ${ }^{20,21}$ and polymer scaffold ${ }^{22,23}$ have been applied to stimulate bone growth and bone healing. Moreover, our pilot work also demonstrated that $\mathrm{Si}-\mathrm{TiO}_{2}$ nanotubes on the surface of $\mathrm{Ti}$ substrates could enhance their biocompatibility and osteogenic activity. ${ }^{24,25}$ However, the in vivo osseointegration was not comprehensively evaluated in our previous studies.

Therefore, in this study, the Ti screws were surface modified with $\mathrm{Si}_{-} \mathrm{TiO}_{2}$ nanotubes through in situ anodization and Si plasma immersion ion implantation (PIII), which is a versatile process and commonly used for the surface modification. To confirm the effects of the nanotubular structures and biochemical cues on osteogenic activity of Ti implants, both in vitro cell, and in vivo animal experiments were conducted. Accordingly, three kinds of samples, pure Ti implant (termed as Ti group), Ti implant surface modified with $\mathrm{TiO}_{2}$ nanotubes $\left(\mathrm{TiO}_{2}-\right.$
NTs group) or $\mathrm{Si}-\mathrm{TiO}_{2}$ nanotubes $\left(\mathrm{Si}-\mathrm{TiO}_{2}-\mathrm{NTs}\right.$ group) were prepared.

\section{Materials and Methods}

\section{Sample Preparation}

Commercial pure Ti discs with the same thickness $(1 \mathrm{~mm})$ and different diameter $(5.8 \mathrm{~mm}, 13 \mathrm{~mm}$ and $31 \mathrm{~mm})$ were used for the in vitro experiment $(\mathrm{Cp} \mathrm{Ti}$, TA1, purity $>99.85 \%$ ). For in vivo experiments, pure Ti screws with a length of $10 \mathrm{~mm}$, outer thread diameter of $2.0 \mathrm{~mm}$, inner thread diameter of $1.7 \mathrm{~mm}$ were employed. These titanium-based materials were supplied by Tianjin Zhengtian Medical Device Company. Disk samples were polished to a near mirror finish and ultrasonically cleaned in acetone, ethanol and ultra-pure water prior to use. $\mathrm{TiO}_{2}$-NTs samples were prepared by anodization according to the method described in our previous work. ${ }^{26}$

Then, $\mathrm{Si}_{-} \mathrm{TiO}_{2}$-NTs were produced by Si-PIII with a filtered cathodic arc plasma source. ${ }^{24,25}$ In brief, the 99.99\% pure silicon rods were used as the cathode. During Si-PIII, a negative pulse voltage of $20 \mathrm{kV}$ was applied, the main arc current and pulsed high voltage applied to target was synchronized at a pulsing frequency of $8 \mathrm{~Hz}$. The pulse duration of the high voltage was 450 ms the same as the pulse duration of the cathodic arc current. The chamber pressure was $4.0 \times 10^{-3} \mathrm{~Pa}$, and the temperature of sample stage was kept at approximately $25^{\circ}$ $\mathrm{C}$ by circulating water.

\section{Surface Characterizations}

The surface morphologies of the samples before and after PIII were examined by scanning electron microscopy (SEM, S3400, Hitachi, Japan). The surface wettability was assessed using a contact angle instrument (SL200B, Solon, China) according to previous works. ${ }^{27}$

\section{Cell Culture}

MC3T3-E1 mouse pre-osteoblasts (CRL-2594, subclone 14, ATCC) were cultured in alpha minimum essential medium ( $\alpha$-MEM, Gibco) with 10\% FBS (Gibco) and 1 $\%$ penicillin/streptomycin under $37^{\circ} \mathrm{C}$, five percent $\mathrm{CO}_{2}$ environment. The $\mathrm{Ti}, \mathrm{TiO}_{2}$-NTs and $\mathrm{Si}-\mathrm{TiO}_{2}$-NTs with the diameter of $5.8 \mathrm{~mm}$ were placed in 96 -well tissue culture plates, and the density of the cells initially seeded was $1 \times 10^{4}$ cells/well. The $\mathrm{Ti}, \mathrm{TiO}_{2}$-NTs and $\mathrm{Si}-\mathrm{TiO}_{2}$-NTs discs $(\Phi, 13 \mathrm{~mm})$ were placed on 24-well plates and the cell density was $3 \times 10^{4}$ cells/well. The $\mathrm{Ti}, \mathrm{TiO}_{2}-\mathrm{NTs}$ and Si- 
$\mathrm{TiO}_{2}$-NTs discs $(\Phi, 31 \mathrm{~mm})$ were placed on six-well polystyrene plates and the cell density was $3 \times 10^{5}$ cells/ well. In the osteogenic differentiation assay, after the cells were cultured for $24 \mathrm{~h}, 10 \mathrm{mM} \beta$-glycerol phosphate, 50 $\mu \mathrm{g} / \mathrm{mL}$ ascorbic acid, and $10 \mathrm{nM}$ dexamethasone were added in the medium as the osteogenic induction medium. The cultured media were refreshed every three days.

\section{Cell Morphology}

The MC3T3-E1 cells were seeded on $\mathrm{Ti}, \mathrm{TiO}_{2}$-NTs and $\mathrm{Si}$ $\mathrm{TiO}_{2}$-NTs $(\Phi, 5.8 \mathrm{~mm})$, respectively, for observing cell morphology. After culturing cells for one, three, and five days, the samples were washed twice with PBS and fixed with $2.5 \%$ glutaraldehyde (Sigma, USA) in PBS for one hour. After rinsing three times with PBS for $10 \mathrm{~min}$, the samples were dehydrated in a graded series of ethanol $(30 \%, 50 \%, 70 \%, 90 \%$, and $100 \%)$ for $30 \mathrm{~min}$ each. The samples were dried through a CPD030 Critical Point Dryer (Leica Microsystems, Germany) and sputter-coated with a gold layer using a Hitachi E-1010 Ion Sputter (Quorum Technologies, Laughton, East Sussex UK). Finally, the morphology of cells was observed by SEM (Quanta, USA).

\section{MTS Assay}

The MC3T3-E1 cells were seeded on $\mathrm{Ti}, \mathrm{TiO}_{2}$-NTs and Si$\mathrm{TiO}_{2}$-NTs $(\Phi, 5.8 \mathrm{~mm})$ for MTS assay. After cell culture for one, three, and five days, the samples were washed three times with PBS to eliminate nonviable cells and transferred to a new 96-well plate for analyzing those cells on the surface of Ti substrates. Then $100 \mu \mathrm{L}$ of culture medium and $20 \mu \mathrm{L}$ of MTS reagent (Promega, USA) were added to each well following the manufacturer's directions. After incubating for two hours, the absorbance of each solution was measured at a wavelength of $490 \mathrm{~nm}$ using a 96-well plate reader on a spectrophotometer (Spectrophotometer U-3010, Hitachi, Japan).

\section{Calcium Deposition}

After seeding MC3T3-E1 cells and subsequent osteogenic induction culture, the extracellular matrix (ECM) mineralization of cells on the samples was evaluated by alizarin red (Sigma) staining. After osteogenic induction for three and four weeks, the $\mathrm{Ti}, \mathrm{TiO}_{2}-\mathrm{NTs}$ and $\mathrm{Si}-\mathrm{TiO}_{2}-\mathrm{NTs}$ samples $(\Phi, 13 \mathrm{~mm})$ were fixed in $75 \%$ ethanol for one hour. Then, cells were rinsed with double-distilled water and stained $200 \mu \mathrm{L}$ of $40 \mathrm{mM}$ alizarin red S solution ( $\mathrm{pH}$ 4.1) for $10 \mathrm{~min}$ at room temperature. Afterwards, the unbound stain was washed with distilled water before the images were taken. In the quantitative analysis, the stained samples were dissolved with $0.5 \mathrm{M} \mathrm{HCl}-5 \%$ sodium dodecyl sulphate (SDS) solution for $30 \mathrm{~min}$ at room temperature. ${ }^{28}$ Then, the absorbance of the solution was determined at $405 \mathrm{~nm}$ on a spectrophotometer (Spectrophotometer U-3010, Hitachi, Japan).

\section{Western Blot Analysis}

The MC3T3-E1 cells cultured on $\mathrm{Ti}, \mathrm{TiO}_{2}$-NTs and $\mathrm{Si}$ $\mathrm{TiO}_{2}$-NTs $(\Phi, 31 \mathrm{~mm})$ were harvested at weeks one, two, and three, respectively. Thirty micrograms of cell lysate were separated by $12 \%$ SDS-PAGE gels and transferred to nitrocellulose membranes. After blocking in specific monoclonal anti- $\beta$-actin (ab3280) primary antibodies (Abcam Biotechnology) HRP conjugated immunoglobulin was used as the secondary antibody (Jackson ImmunoResearch Laboratories). Then, West Pico Chemiluminescent (Pierce) was adopted as the substrate to visualize protein bands, which were quantified using densitometry image analysis software (Image Master VDS, Pharmacia Biotech). Normalization was made against $\beta$-actin expression.

\section{In vivo Osseointegration Study Surgical Implantation}

All the animal experiments were approved by the Institutional Animal Care and Use Committee (IACUC) of Soochow University, and all procedures followed the NIH guidelines for the care and use of laboratory animals. Thirtysix male Sprague Dawley rats (260-280 g weight) supplied by Soochow University Animal Center were used for the animal experiment. Among them, 27 rats were used for mechanical tests and nine rats for micro-CT and histological analysis. Implantations were divided into three groups as follows: $\mathrm{Ti}$ (pure $\mathrm{Ti}$ screws), $\mathrm{TiO}_{2}$-NTs ( $\mathrm{Ti}$ screws modified by $\mathrm{TiO}_{2}$ nanotubes), and $\mathrm{Si}-\mathrm{TiO}_{2}$-NTs (Ti screws modified by $\mathrm{Si}_{-} \mathrm{TiO}_{2}$ nanotubes). Systemic anesthesia injection was adopted using ketamine and xylazine at $80-100 \mathrm{mg} / \mathrm{kg}$ and $10-20 \mathrm{mg} / \mathrm{kg}$, respectively. Additional local anesthesia was also performed in the surgery field with $2 \%$ lidocaine solution containing epinephrine $(1: 100,000)$. The hair of surgical site was removed and sterilized with betadine scrubs. Flat surface of the distal femur was selected for implant placement. The screws were implanted from the outside to the inside in the horizontal direction. Each rat received one implant ( $\mathrm{Ti}, \mathrm{TiO}_{2}-\mathrm{NTs}$ or $\left.\mathrm{Si}-\mathrm{TiO}_{2}-\mathrm{NTs}\right)$ in each femur. At the tenth and third day before sacrifice, the animals received 
subcutaneous injections of fluorochrome label (calcein). The experimental animals were sacrificed at the time by an intraperitoneal excessive dose of sodium pentobarbital.

\section{Mechanical Tests}

Three rats of each group were sacrificed at two, four, and six weeks after surgery. Pull-out tests were performed for all implants (six samples per group) in the femur. The femurs were mounted in the machine with the head of the screw pointing out of a hole in a metal book holder (Figure 1). The screws were tested for pull-out strength using a mechanical testing machine (HY-1080, Shanghai, China). A load cell (maximum force of $500 \mathrm{~N}$ ) at a test speed of $1 \mathrm{~mm} / \mathrm{min}$ was applied. The maximal force during the pull-out experiment was considered as the pull-out force.

\section{Micro-CT and Histological Analysis}

After six weeks, the nine rats were sacrificed and each group had six samples for micro-CT analysis. The bonescrew interface and trabecular microstructure of specimens were scanned on a micro-CT system ( $18 \mu \mathrm{m}$ voxel size, 80 $\mathrm{kV}, 300 \mu \mathrm{A}, 290 \mathrm{~min}$ exposure time, $\mathrm{Cu}$ and $\mathrm{Al} \mathrm{filter,} 0.7^{\circ}$ rotation step; SkyScan1176 In vivo Micro-CT, Brüker, Kontich, Belgium). Multilevel thresholding procedures (threshold for bone $=75$, threshold for implant $=115$ ) were applied to discriminate bone from other tissue. The volume of interest (VOI) included the trabecular compartment extending $1.4 \mathrm{~mm}$ from the longitudinal axis of the screw.

After micro-CT scan, the distal femurs with screws were prepared for undecalcified histologic sections, each group had six samples for histological analysis. All implant sites were processed through gradient ethanol dehydration and xylene substitute before being infiltrated and embedded in methyl methacrylate to individually labeled blocks.

\section{Statistical Analysis}

Quantitative data were expressed as the mean \pm SD. Statistical analysis was performed with unpaired
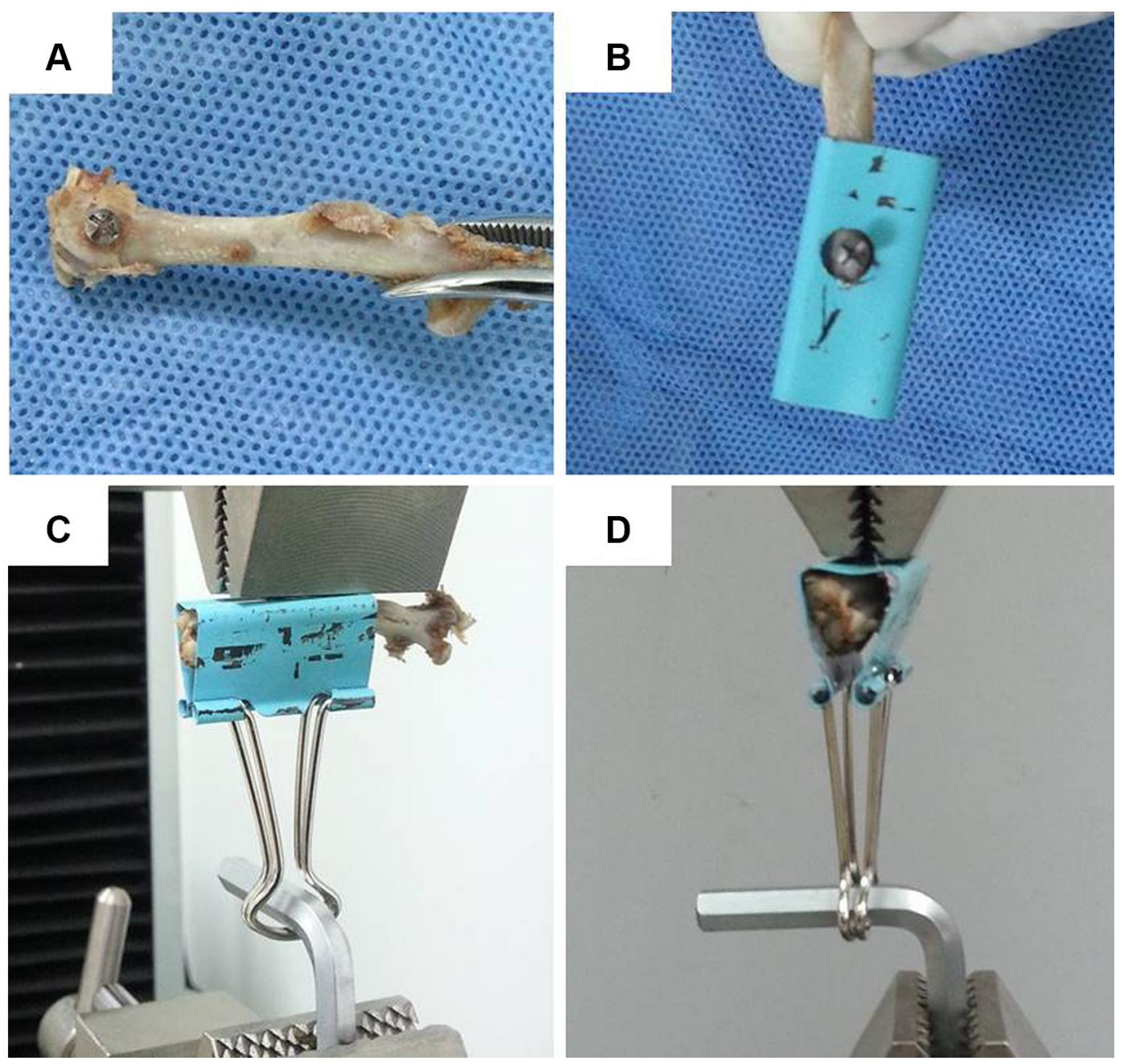

Figure I Experimental set-up for pull-out analyses: (A) The position of screw at the distal femur, and (B-D) show the mounted femur in the material testing machine. 
two-tailed Student's $t$-test for single comparisons with SPSS 18.0 (SPSS Inc., Chicago, IL, USA). ANOVA was used to compare data from more than two groups. A value of $p<0.05$ denotes statistically significant difference.

\section{Results}

\section{Surface Properties of Modified Ti Substrates}

Figure $2 \mathrm{~A}$ and $\mathrm{B}$ show the SEM images of $\mathrm{TiO}_{2}-\mathrm{NTs}$ and $\mathrm{Si}^{-\mathrm{TiO}_{2}}$-NTs. After anodization, the surface of titanium substrate showed a regular tubular nanostructure, and the outer and inner diameter of these nanotubes are about 80 $\mathrm{nm}$ and $60 \mathrm{~nm}$, respectively (Figure 2A and B). Treated by Si-PIII, the nanotubular structures could still be observed but some pores are enclosed. The water contact angles of $\mathrm{Si}-\mathrm{TiO}_{2}-\mathrm{NTs}, \mathrm{TiO}_{2}-\mathrm{NTs}$ and pure $\mathrm{Ti}$ are $11.25 \pm 0.88^{\circ}$, $35.89 \pm 1.38^{\circ}$ and $65.14 \pm 4.05^{\circ}$, respectively (Figure $2 \mathrm{CE}$ ). The results indicate that $\mathrm{Si}_{-} \mathrm{TiO}_{2}$-NTs were more hydrophilic than $\mathrm{TiO}_{2}$-NTs and Ti.

\section{Cell Morphology}

Cell morphology on $\mathrm{Ti}, \mathrm{TiO}_{2}$-NTs and $\mathrm{Si}-\mathrm{TiO}_{2}$-NTs at one, three, and five days was observed by SEM, as shown in Figure 3. After one day of cultivation, cells on the Ti show a flattened morphology, meanwhile the cells on $\mathrm{TiO}_{2}-\mathrm{NTs}$ and $\mathrm{Si}-\mathrm{TiO}_{2}$ NTs are round and irregular shape. Moreover, finger-like filopodia extensions could be observed on the $\mathrm{Si}^{-\mathrm{TiO}_{2}}$-NTs. At day three, the cells on the $\mathrm{Ti}$ and $\mathrm{TiO}_{2}$-NTs exhibit elongated and flattened morphology. Filopodia extensions could also be observed on the $\mathrm{Si}^{-\mathrm{TiO}_{2}}$-NTs, on which cells begin to merge. At day five, all the groups are covered with cells. Much more mesh-like filopodia appear on $\mathrm{TiO}_{2}-\mathrm{NTs}$ than $\mathrm{Ti}$, while many filamentous network structures with excellent intercellular attachment could be found on $\mathrm{Si}$ $\mathrm{TiO}_{2}$-NTs.

\section{Cell Proliferation}

Figure 4A shows the MTS assay result of cells cultured on $\mathrm{Ti}, \mathrm{TiO}_{2}$-NTs and $\mathrm{Si}-\mathrm{TiO}_{2}$-NTs for one, three and five days. The cells on all samples proliferate gradually. After one and three days of incubation, cell proliferation on substrate with nanotubular surfaces is higher than that on $\mathrm{Ti}$, and there is no significant difference between $\mathrm{Si}-\mathrm{TiO}_{2}-$ NTs and $\mathrm{TiO}_{2}$-NTs. At day five, cells on $\mathrm{Si}^{-\mathrm{TiO}_{2}}$-NTs were more than on $\mathrm{TiO}_{2}$-NTs, indicating that cell proliferation is enhanced after Si incorporation.

\section{Calcium Deposition}

The results of extracellular matrix mineralization of the MC3T3-E1 cells cultured on three samples are shown in Figure 4B. Compared to $\mathrm{Ti}$, cells on $\mathrm{TiO}_{2}$-NTs and Si$\mathrm{TiO}_{2}$-NTs show more calcium mineral nodule formation both at three and four weeks. Moreover, the amount of deposited calcium mineral on Si-incorporated samples is higher than those on $\mathrm{TiO}_{2}$-NTs at four weeks.
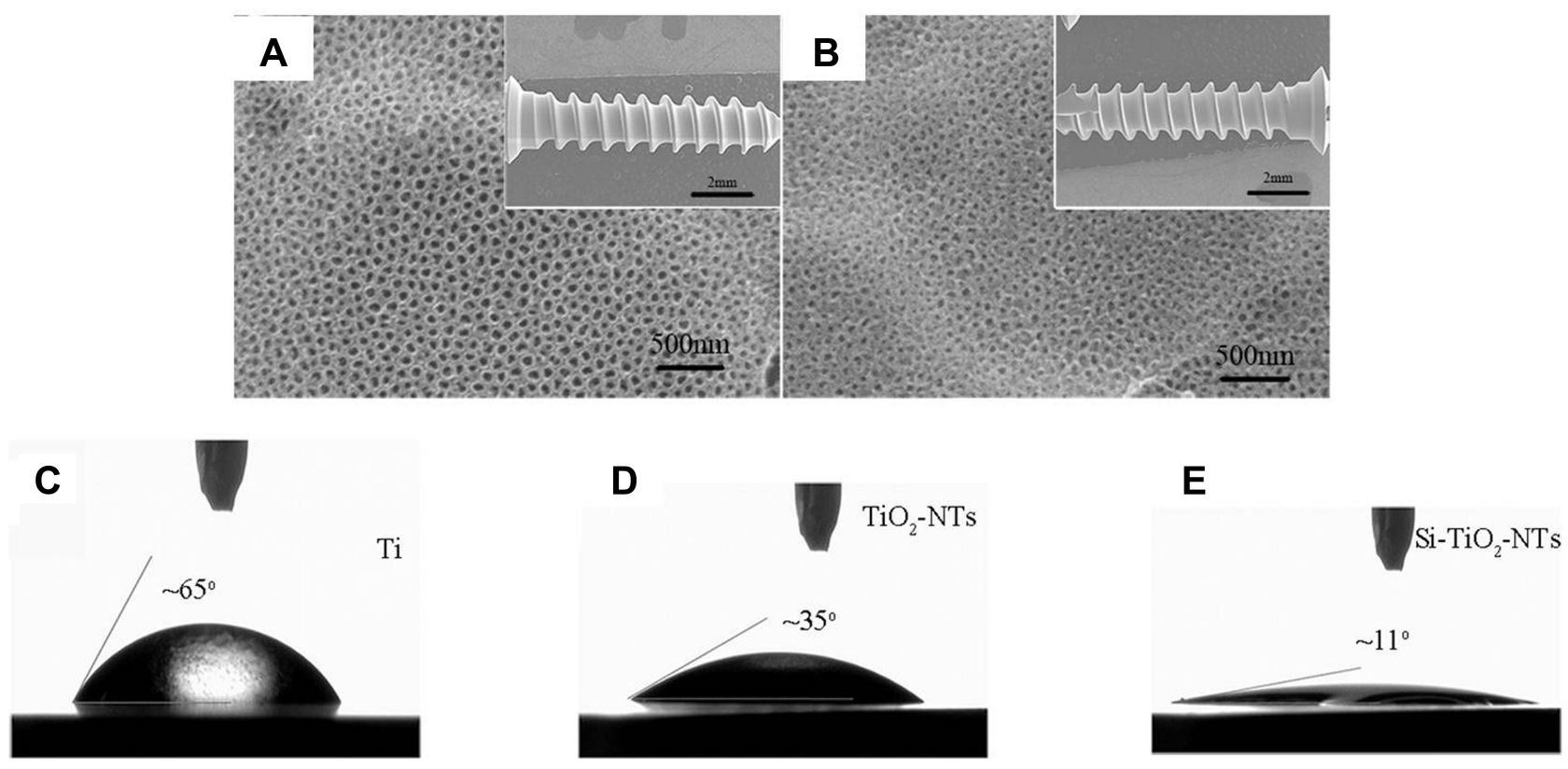

Figure $2 \mathrm{SEM}$ images of the $\mathrm{TiO}_{2}-\mathrm{NTs}(\mathbf{A})$ and $\mathrm{Si}_{-} \mathrm{TiO}_{2}-\mathrm{NTs}(\mathbf{B})$ screws, and water contact angles of $\mathrm{Ti}(\mathbf{C})$, $\mathrm{TiO}_{2}-\mathrm{NTs}(\mathbf{D})$ and $\mathrm{Si}-\mathrm{TiO} \mathbf{2}_{2}-\mathrm{NTs}(\mathbf{E})$. 


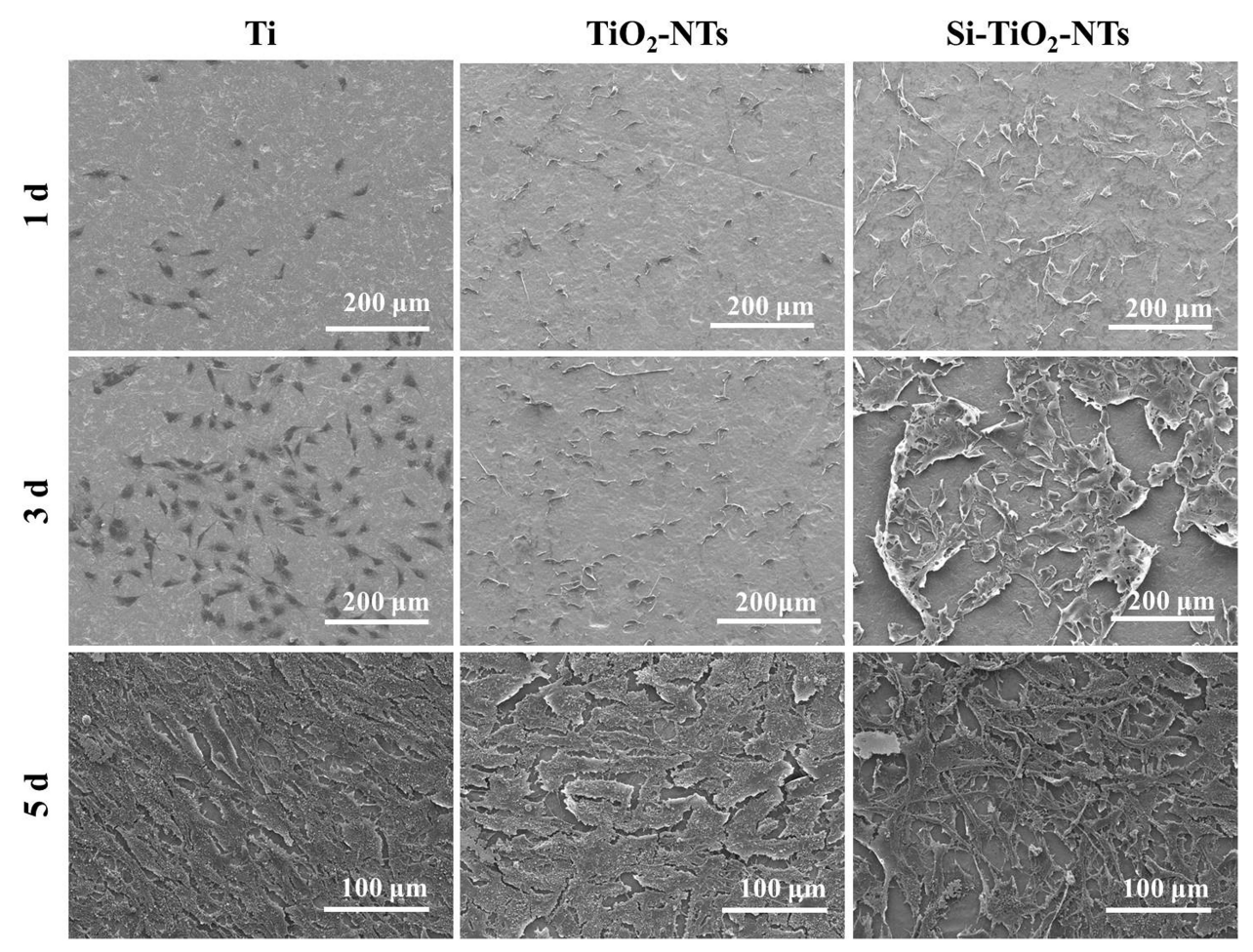

Figure 3 Morphology of MC3T3-EI cultured on $\mathrm{Ti}, \mathrm{TiO}_{2}-\mathrm{NTs}$ and $\mathrm{Si}-\mathrm{TiO}_{2}-\mathrm{NTs}$ for one, three, and five days, respectively.
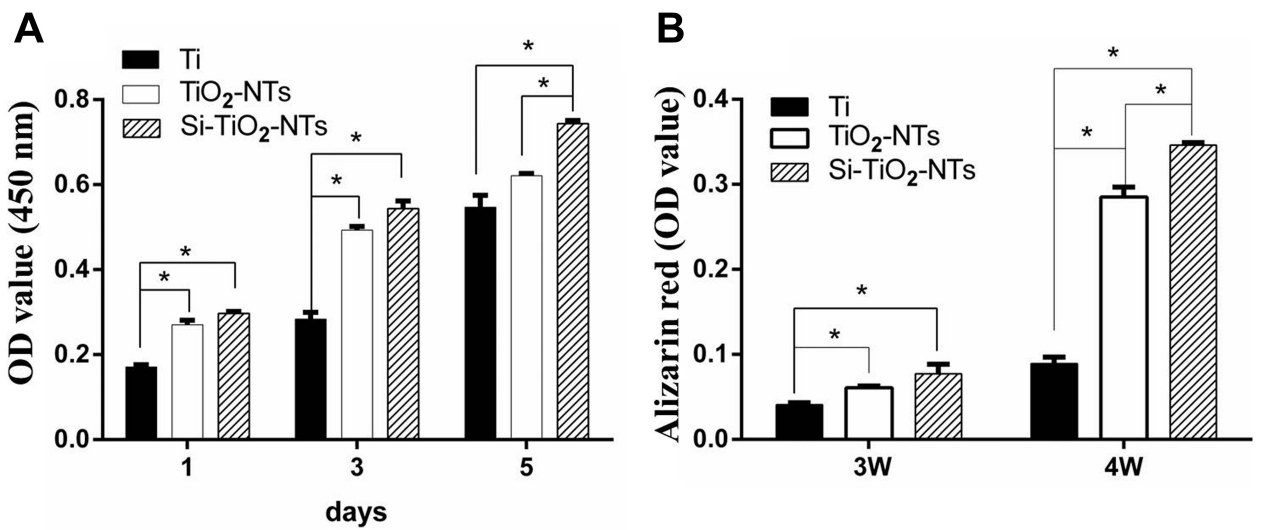

Figure 4 Cell viability and proliferation (A) shown by MTS assay of MC3T3-EI cells cultured on $\mathrm{Ti}, \mathrm{TiO}_{2}-\mathrm{NTs}$ and $\mathrm{Si}-\mathrm{TiO}_{2}-\mathrm{NTs}$ for one, three, and five days, and calcium deposition determined $(\mathbf{B})$ by alizarin red staining for -three and four weeks. ${ }^{*} p<0.05$.

\section{Western Blot}

The results of Western blotting analysis are shown in Figure 5. The expressions of Runx2, ALP and Col-I of cells cultured on the three samples are presented and $\beta$ actin was adopted as control (Figure 5A). The quantitative results of proteins expression are also displayed in Figure 5B. An enhanced expression of Runx2 is observed on $\mathrm{Si}-$ $\mathrm{TiO}_{2}$-NTs compared to $\mathrm{TiO}_{2}$-NTs and $\mathrm{Ti}$ at weeks one and three. The levels of ALP expression are obviously increased on $\mathrm{Si}_{-} \mathrm{TiO}_{2}$-NTs rather than $\mathrm{TiO}_{2}$-NTs at week one. The protein expression of Col-I does not show significant difference among these samples.

\section{In vivo Osseointegration Pull-out Force Measurement}

As shown in Figure 6, the pull-out force of $\mathrm{TiO}_{2}$-NTs is significantly higher than Ti. Moreover, the $\mathrm{Si}_{-}-\mathrm{TiO}_{2}-\mathrm{NTs}$ group exhibits the highest pull-out force at two and four weeks. The peak pull-out forces increased approximately $18 \%$ and $21 \%$ on Si-implanted samples than 
A

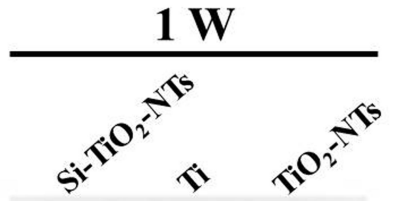

B-actin

unx2

Col- I

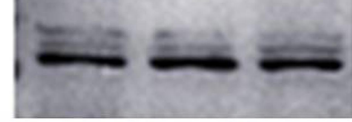

ALP

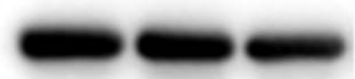

B

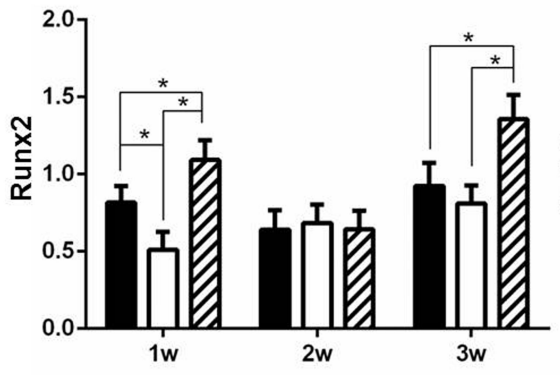

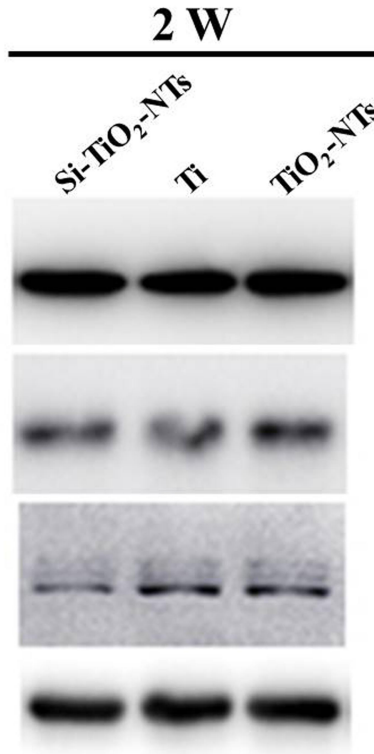

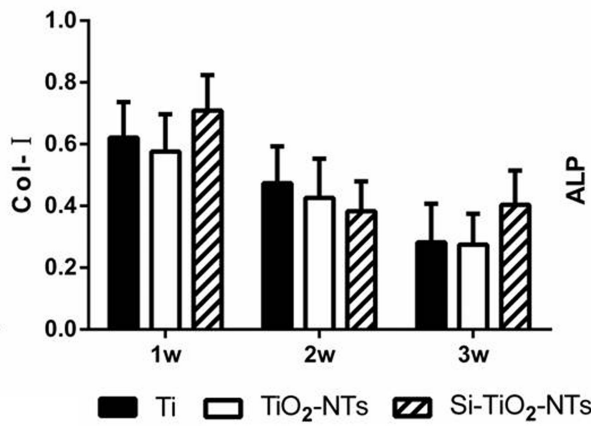

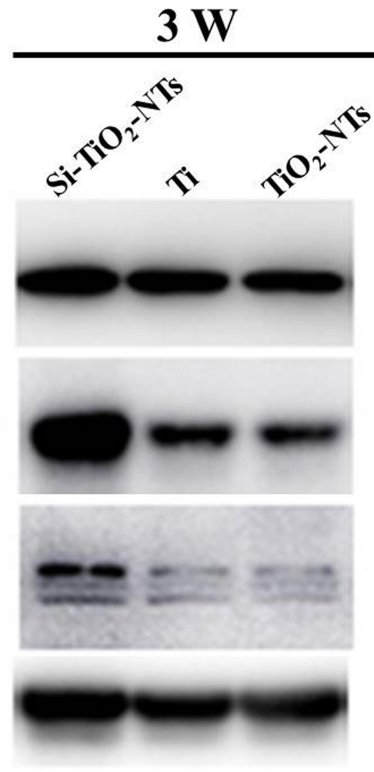

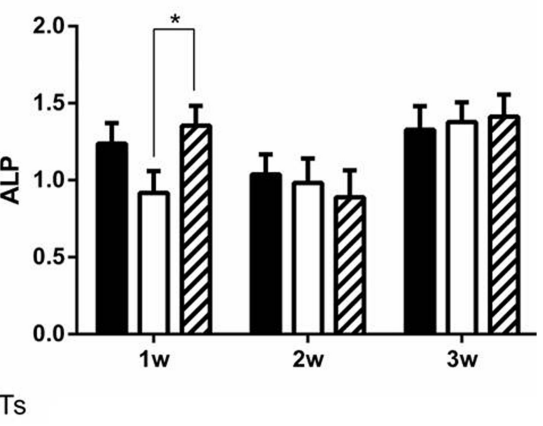

Figure 5 (A) Protein expression of Runx2, Collage I and ALP of MC3T3-EI cells cultured on Ti, TiO ${ }_{2}-\mathrm{NTs}$ and $\mathrm{Si}^{-} \mathrm{TiO}_{2}-\mathrm{NT}$ s determined by Western blot, $\beta$-actin was used as the control, and (B) are the corresponding relative intensity. ${ }^{*}<<0.05$.

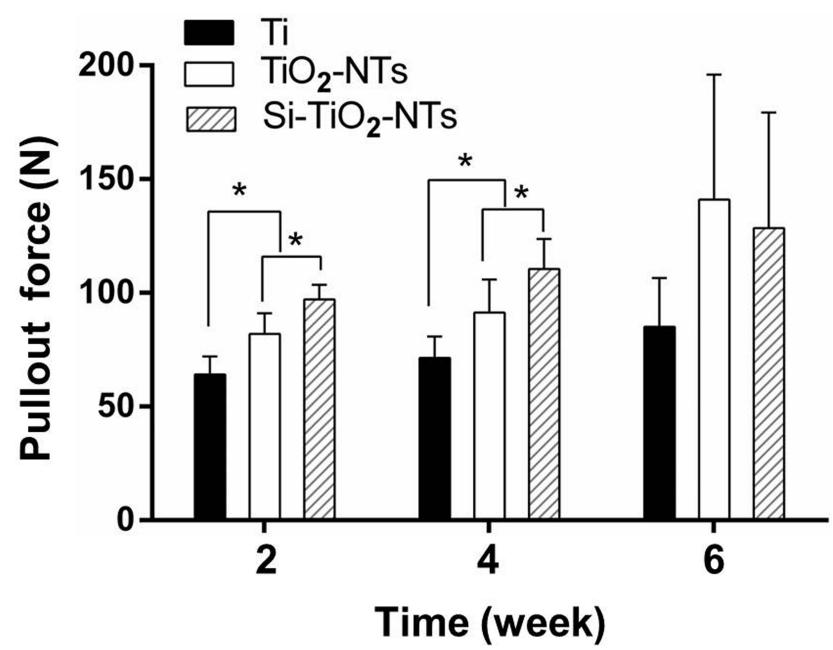

Figure 6 Pullout forces of screws removal after implantation in rat femurs. ${ }^{*} p<0.05$.

$\mathrm{TiO}_{2}$-NTs at weeks two and four, respectively. At week six, there was no significant difference among the three samples.

\section{Micro-CT and Histological Evaluations}

The results of micro-CT six weeks after surgery are shown in Figure 7. From the two-dimensional micro-CT images, more cancellous bone is observed around the $\mathrm{Si}-\mathrm{TiO}_{2}-\mathrm{NTs}$ screws than the controls (Figure 7A). Quantitative evaluation is presented in Figure $7 \mathrm{~B}$, and more detailed information is obtained on percentage osteointegration ( $\% \mathrm{OI})$ and trabecular parameters around screws. Compared to Ti screws, the $\%$ OI of $\mathrm{Si}-\mathrm{TiO}_{2}-\mathrm{NTs}$ and $\mathrm{TiO}_{2}-\mathrm{NTs}$ increases to $65 \%$ and $54 \%$, respectively. The bone volume ratio (BV/TV) values of Si-TiO $2-\mathrm{NTs}$ and $\mathrm{TiO}_{2}-\mathrm{NTs}$ are about 4.2-fold and 2.4-fold than that of Ti. In addition, the trabecular thickness (Tb.Th), trabecular number (Tb.N) and trabecular separation (Tb.Sp) of $\mathrm{Si}-\mathrm{TiO}_{2}-\mathrm{NTs}$ and $\mathrm{TiO}_{2}-\mathrm{NTs}$ are all higher than that of Ti.

The histological images are displayed in Figure 8. The fluorochrome labels reflect the different patterns of bone neoformation and remodeling in three groups. Extensive bone apposition could be found between the screw threads at the spongy level on the $\mathrm{Si}-\mathrm{TiO}_{2}-\mathrm{NT}$ and $\mathrm{TiO}_{2}-\mathrm{NT}$. 

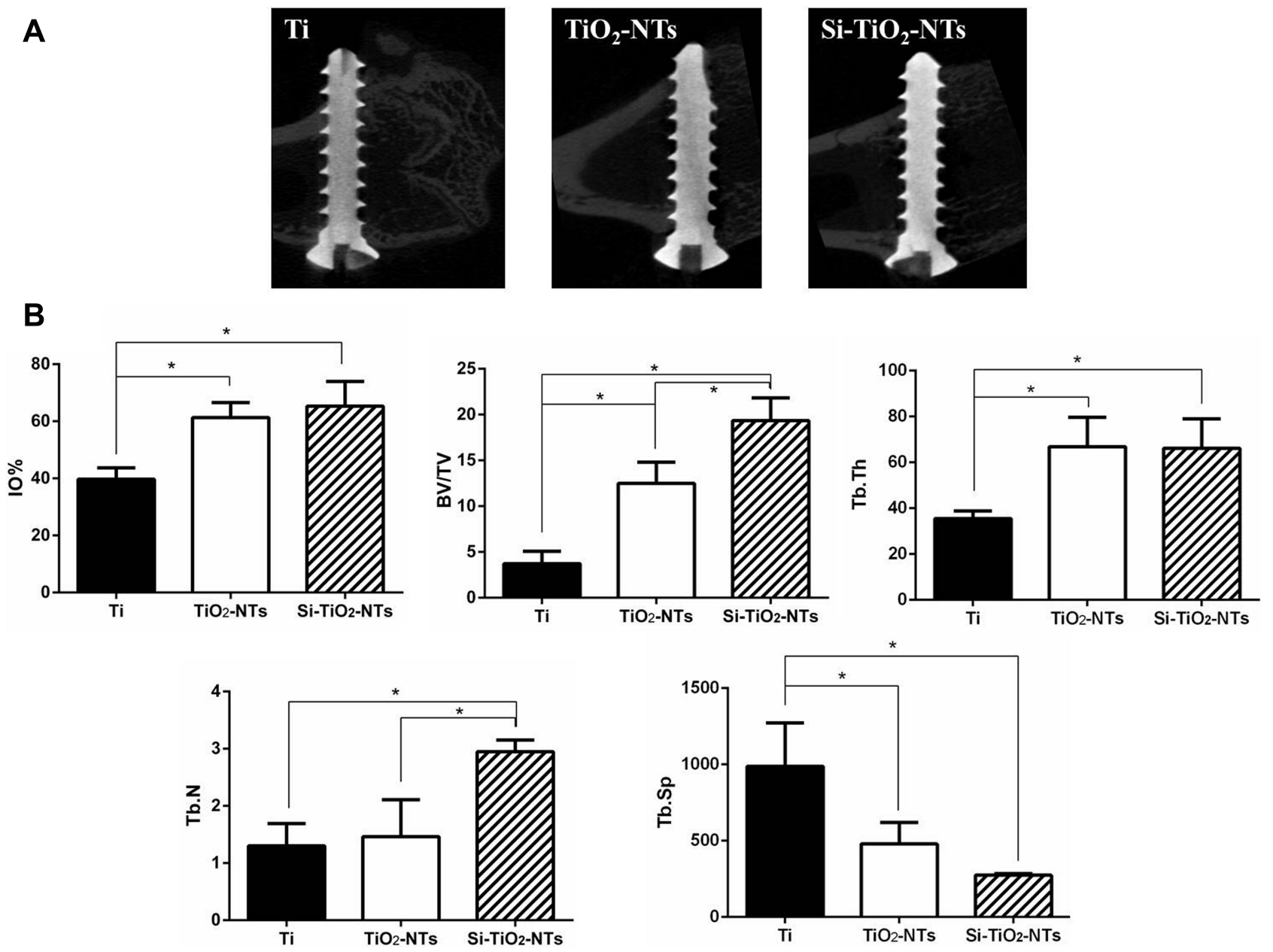

Figure 7 (A) The 2D micro-CT images of the sections along the plane of femurs, and (B) histograms of percentage osseointegration and trabecular parameters within volume of interest. $* p<0.05$.

Abbreviations: \% Ol, percentage osseointegration; BV/TV, trabecular bone volume density; Tb.Th, trabecular thickness; Tb.N, trabecular number; Tb.Sp, trabecular separation.

And more bone is observed at the internal part of the Si$\mathrm{TiO}_{2}$-NTs screw compared to $\mathrm{TiO}_{2}$-NTs, indicating a new bone trabecular formation on the surface of $\mathrm{Si}_{-} \mathrm{TiO}_{2}-\mathrm{NTs}$ screw.

\section{Discussion}

Due to the nature of bio-inertness, titanium-based implants can lead to capsule formation after hip or knee replacement surgery and the bone bonding tends to become loose over the long term. ${ }^{29}$ Thus, surface modifications are essential for titanium-based implants to achieve better and more rapid bonding to bone. Surface topography ${ }^{30}$ and surface chemical compositions, ${ }^{31}$ the two major factors, can affect the interactions between implants and cells/ tissues. In this work, titanium screws surface-modified with $\mathrm{Si}-\mathrm{TiO}_{2}$ nanotubes were produced and their osteogenesis potential was investigated. Further, titanium screws and titanium screws surface-modified with $\mathrm{TiO}_{2}$ nanotubes were adopted as the controls, it may help to understand the roles of nanostructured surface and incorporation of silicon in regulating osteogenesis.

$\mathrm{Si}$ was incorporated into the $\mathrm{TiO}_{2}$ nanotubes on the surface of Ti screws using Si-PIII technique described in our previous studies. ${ }^{24,25}$ With this method, Si could be successfully incorporated into $\mathrm{TiO}_{2}$-NTs. ${ }^{25}$ After Si-PIII treatment, a nanotubular surface was obtained (Figure 2A and $\mathrm{B})$. According to the results of water contact angle, the surface wettability of $\mathrm{TiO}_{2}$-NTs is better than pure $\mathrm{Ti}$ (Figure 2C and D), which could be attributed to the existence of $\mathrm{TiO}_{2}$ nanotubes on the surface of Ti screws. ${ }^{19}$ Further, it is found that a more hydrophilic surface was obtained after Si incorporation. Another study has demonstrated that the existence of Ti-O-Si on the surface of Si$\mathrm{TiO}_{2}$ could improve the hydrophilicity and the capability 

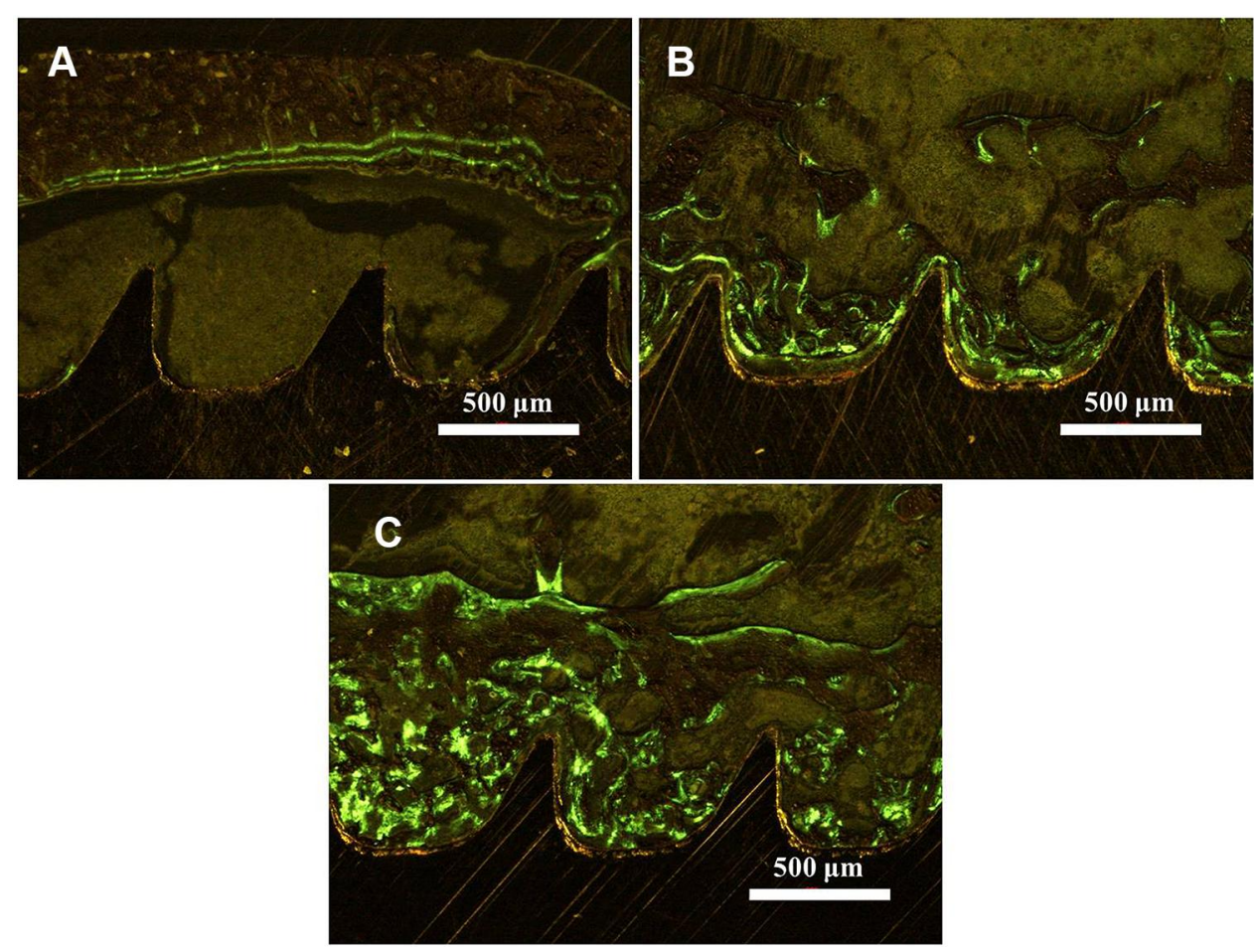

Figure 8 Histological appearance of $\mathrm{Ti}(\mathbf{A}), \mathrm{TiO}_{2}-\mathrm{NTs}(\mathbf{B})$ and $\mathrm{Si}-\mathrm{TiO}_{2}-\mathrm{NTs}(\mathbf{C})$ samples after six weeks of implantation, Green (calcein) lines are presented as the new bone around the screw. Scale bars, $500 \mu \mathrm{m}$.

to hold absorbed water compared to $\mathrm{TiO}_{2}$ film. ${ }^{32}$ In our current study, Ti-O-Si also existed on the surface of Si$\mathrm{TiO}_{2}-\mathrm{NTs}$, resulting in the better hydrophilicity of $\mathrm{Si}^{-\mathrm{TiO}_{2}-}$ NTs compared with $\mathrm{TiO}_{2}$-NTs. Moreover, our previous study also found that the hydrophilicity of the Ti substrates increases with the incorporated $\mathrm{Si}$ amount. ${ }^{24}$

The adhesion of cells on implant surfaces is the first stage after in vivo implantation, which defines the quality of the bone bonding. ${ }^{33}$ When the cells were cultured on the samples for one, three, and five days, the cells were observed with good adhesion on $\mathrm{TiO}_{2}-\mathrm{NTs}$ than $\mathrm{Ti}$, which may be attributed to the nanostructures on the surface (Figure 3). Oh et al had pointed out that the tubular structures could improve cell adhesion by generating an interlocked structure when cell filopodia went into the pores. ${ }^{12}$ Moreover, the cells on the $\mathrm{Si}-\mathrm{TiO}_{2}$ nanotubes showed the best filopodia activities, which may be attributed to the nanostructures and hydrophilic surface. Furthermore, the proliferation of cells was studied by MTS test for one, three, and five days (Figure 4A). Improved cell proliferation was observed on the samples with nanotubular structures. Interestingly, cell proliferation appeared faster at day five on $\mathrm{Si}-\mathrm{TiO}_{2}-\mathrm{NTs}$ than on $\mathrm{TiO}_{2}-$ NTs, which may be related to the $\mathrm{Si}$ incorporation. A recent study also demonstrated the potential of $\mathrm{Si}$ - contained biomaterials for patterned cell culture in vitro. ${ }^{34}$ Other research groups had reported that the existence of $\mathrm{Si}$ could improve the metabolism, synthetic activity and osteogenic activity of the cells. ${ }^{17,35}$

To further verify the enhancement of $\mathrm{Si}$ on osteogenic activity, the matrix mineralization was investigated by alizarin red S staining (Figure 4B). As a marker of osteogenic activity, the matrix mineralization of $\mathrm{TiO}_{2}-\mathrm{NTs}$ was more than $\mathrm{Ti}$ without this surface microstructure. The incorporation of $\mathrm{Si}$ in $\mathrm{TiO}_{2}-\mathrm{NTs}$ further enhanced matrix mineralization (Figure 4B). This result showed that the existence of $\mathrm{Si}$ and $\mathrm{TiO}_{2}$ nanotubes could promote osteogenic activity. Although the expression of osteogenesisrelated genes was not detected in this study, in our previous study these genes were observed upregulated. ${ }^{24}$ In this study, we further determined the expression of osteogenesis-related proteins by Western blotting analysis. Runx2 and ALP, which are early markers for osteogenic differentiation, have been widely used to investigate osteogenic activity. ${ }^{36,37}$ Both the expression of Runx2 and ALP increased on $\mathrm{Si}_{-}-\mathrm{TiO}_{2}-\mathrm{NTs}$ than $\mathrm{Ti}$ and $\mathrm{TiO}_{2}-\mathrm{NTs}$ (Figure 5). Increased expression of Runx 2 occurred at weeks one and three, and ALP at week one. Moreover, Col-I is the main content of bone ECM, its expression was higher on $\mathrm{Si}-\mathrm{TiO}_{2}-\mathrm{NTs}$ although there is no significant difference 
among the three samples. Comparing the results of these three groups, it was found that the existence of $\mathrm{Si}$ and $\mathrm{TiO}_{2}$ nanotubes exhibited the highest osteogenic activity in vitro. These findings are consistent with previous studies, in which $\mathrm{Si}$ incorporated $\mathrm{TiO}_{2}$ on titanium showed enhanced osteogenic activity. ${ }^{24,38-40}$

In vivo osteogenesis of $\mathrm{Si}-\mathrm{TiO}_{2}-\mathrm{NTs}, \mathrm{TiO}_{2}-\mathrm{NTs}$ and $\mathrm{Ti}$ screws after insertion into the distal femur of rats were studied. After two and four weeks, the pull-out force of $\mathrm{Si}-\mathrm{TiO}_{2}-\mathrm{NTs}$ group increased about $18 \%$ and $21 \%$ than those of $\mathrm{TiO}_{2}$-NTs (Figure 6). By six weeks, the pull-out force showed no significant differences among all the groups. The reason might be that rate of bone formation in rats could be achieved in 28 days, that was much faster than the implants in humans. ${ }^{41}$ Further, the values of BV/TV, Tb. Th and Tb.N as well as Tb.Sp of $\mathrm{TiO}_{2}-\mathrm{NTs}$ were significantly higher than Ti screw. Further, the BV/TV and Tb.N of $\mathrm{Si}-\mathrm{TiO}_{2}-\mathrm{NTs}$ showed a significant improvement (Figure 7). The results demonstrated that the treatments of nanostructured surface production and silicon implantation had a positive effective effect on implant osseointegration and trabecular microarchitecture formation.

In addition, histological analysis was also performed on the tissue/implant interface to evaluate the bone response on the implants during the healing process. The images showed the bone regeneration capacity of the different screw surfaces (Figure 8). All the three materials ( $\mathrm{Ti}, \mathrm{TiO}_{2}-\mathrm{NTs}$ and $\mathrm{Si}-\mathrm{TiO}_{2}-\mathrm{NTs}$ ) exhibited new bone formation within six weeks and newly mineralized trabecular bone was formed between screw threads (green region). Further, a tight and direct bone bonding between the bone and screws modified with $\mathrm{Si}-\mathrm{TiO}_{2}-\mathrm{NTs}$ can be observed. In the endosteal region, fluorochrome labels evidenced that a parallel disposition was formed and constituted the internal circumferential lamellae. The similar results of Siinduced bone formation and growth were also observed by others, such as the enhanced longitudinal development of the femur in the Si-OVX group. ${ }^{42}$

\section{Conclusions}

In this work, $\mathrm{Si}_{-} \mathrm{TiO}_{2}$ nanotubes were prepared on the surface of Ti screws. In vitro results show that cells cultured on $\mathrm{Si}$ containing nanotubes exhibited better cell adhesion, proliferation and matrix mineral deposition as well as upregulated expression of osteogenic-related proteins. In vivo osseointegration studies revealed that early-stage new bone formation was promoted on $\mathrm{Ti}$ screws modified by $\mathrm{Si}-\mathrm{TiO}_{2}$ nanotubes. These results indicate that the $\mathrm{Si}-\mathrm{TiO}_{2}-\mathrm{NTs}$ combining nanostructure and Si element have the ability to accelerate osseointegration of Ti screws, which would have large potential in improving the properties of $\mathrm{Ti}$ implants.

\section{Acknowledgments}

The authors are very grateful to Prof. Xuanyong Liu from Shanghai Institute of Ceramics, Chinese Academy of Sciences for providing the materials and technical assistance for this study. The authors are also grateful to the funding support from National Natural Science Foundation of China (31530024, 31872748), Municipal Health and Family Planning Committee of Wuxi (MS201726), Jiangsu Provincial Special Program of Medical Science (BL2012004), and the Priority Academic Program Development of Jiangsu Higher Education Institutions.

\section{Disclosure}

The authors report no conflicts of interest in this work.

\section{References}

1. Long M, Rack HJ. Titanium alloys in total joint replacement-a materials science perspective. Biomaterials. 1998;19:1621-1639. doi:10.1016/S0142-9612(97)00146-4

2. Wang L, Yang X, Cao WW, et al. Mussel-inspired deposition of copper on titanium for bacterial inhibition and enhanced osseointegration in a periprosthetic infection model. RSC Adv. 2017;7:5159351604. doi:10.1039/C7RA10203H

3. Gao CC, Wang Y, Han FX, et al. Antibacterial activity and osseointegration of silver-coated poly (ether ether ketone) prepared using the polydopamine-assisted deposition technique. $J$ Mater Chem $B$. 2017;5:9326-9336. doi:10.1039/C7TB02436C

4. Jia L, Han F, Wang H, et al. Polydopamine-assisted surface modification for orthopaedic implants. J Orthop Transl. 2019;17:82-95. doi:10.1016/j.jot.2019.04.001

5. Lausmaa J, Linder L. Surface spectroscopic characterization of titanium implants after separation from plastic-embedded tissue. Biomaterials. 1988;9:277-280. doi:10.1016/0142-9612(88)90098-1

6. Albrektsson T, Sennerby L. Direct bone anchorage of oral implants: clinical and experimental considerations of the concept of osseointegration. Int J Prosthodont. 1990;3:30-41.

7. Chouirfa H, Bouloussa H, Migonney V, Falentin-Daudre C. Review of titanium surface modification techniques and coatings for antibacterial applications. Acta Biomater. 2019;83:37-54. doi:10.1016/j. actbio.2018.10.036

8. Oh S, Brammer KS, Li YS, et al. Stem cell fate dictated solely by altered nanotube dimension. P Natl Acad Sci USA. 2009;106:21302135. doi: $10.1073 /$ pnas.0813200106

9. Zemtsova EG, Yudintceva NM, Morozov PE, Valiev RZ, Smirnov VM, Shevtsov MA. Improved osseointegration properties of hierarchical microtopographic/nanotopographic coatings fabricated on titanium implants. Int J Nanomed. 2018;13:2175-2188. doi:10.21 47/IJN.S161292

10. Sul YT, Johansson CB, Petronis S, et al. Characteristics of the surface oxides on turned and electrochemically oxidized pure titanium implants up to dielectric breakdown: the oxide thickness, micropore configurations, surface roughness, crystal structure and chemical composition. Biomaterials. 2002;23:491-501. doi:10.1016/S01429612(01)00131-4 
11. Variola F, Brunski JB, Orsini G. Nanoscale surface modifications of medically relevant metals: state-of-the art and perspectives. Nanoscale. 2011;3:335-353. doi:10.1039/c0nr00485e

12. Oh S, Daraio C, Chen LH, Pisanic TR, Finones RR, Jin S. Significantly accelerated osteoblast cell growth on aligned $\mathrm{TiO}_{2}$ nanotubes. J Biomed Mater Res A. 2006;78:97-103. doi:10.1002/ jbm.a.30722

13. Das $\mathrm{K}$, Bose $\mathrm{S}$, Bandyopadhyay $\mathrm{A}$. $\mathrm{TiO}_{2}$ nanotubes on $\mathrm{Ti}$ : influence of nanoscale morphology on bone cell-materials interaction. $J$ Biomed Mater Res A. 2009;90:225-237. doi:10.1002/jbm.a.32088

14. Ma Q, Jiang N, Liang $\mathrm{S}$, et al. Functionalization of a clustered $\mathrm{TiO}_{2}$ nanotubular surface with platelet derived growth factor-BB covalent modification enhances osteogenic differentiation of bone marrow mesenchymal stem cells. Biomaterials. 2020;230:119650. doi:10. 1016/j.biomaterials.2019.119650

15. Hing KA, Revell PA, Smith N, Buckland T. Effect of silicon level on rate, quality and progression of bone healing within silicate-substituted porous hydroxyapatite scaffolds. Biomaterials. 2006;27:50145026. doi:10.1016/j.biomaterials.2006.05.039

16. O’Neill E, Awale G, Daneshmandi L, Umerah O, Lo KW. The roles of ions on bone regeneration. Drug Discov Today. 2018;23:879-890. doi:10.1016/j.drudis.2018.01.049

17. Xing M, Wang X, Wang E, Gao L, Chang J. Bone tissue engineering strategy based on the synergistic effects of silicon and strontium ions. Acta Biomater. 2018;72:381-395. doi:10.1016/j.actbio.2018.03.051

18. Botelho CM, Brooks RA, Best SM, et al. Human osteoblast response to silicon-substituted hydroxyapatite. $J$ Biomed Mater Res A. 2006;79:723-730. doi:10.1002/jbm.a.30806

19. Qian S, Liu X. Cytocompatibility of Si-incorporated $\mathrm{TiO}_{2}$ nanopores films. Colloids Surf B Biointerfaces. 2015;133:214-220. doi:10.1016/ j.colsurfb.2015.06.007

20. Kermani F, Gharavian A, Mollazadeh S, Kargozar S, Youssefi A, Vahdati Khaki J. Silicon-doped calcium phosphates; the critical effect of synthesis routes on the biological performance. Mater Sci Eng CMater. 2020;111:110828. doi:10.1016/j.msec.2020.110828

21. Karimi M, Mesgar A, Mohammadi Z. Development of osteogenic chitosan/alginate scaffolds reinforced with silicocarnotite containing apatitic fibers. Biomed Mater. 2020;15:055020. doi:10.1088/1748$605 x / a b 954 f$.

22. Wang Y, Cui W, Zhao X, et al. Bone remodeling-inspired dual delivery electrospun nanofibers for promoting bone regeneration. Nanoscale. 2018;11:60-71. doi:10.1039/C8NR07329E

23. Obata A, Tokuda S, Kasuga T. Enhanced in vitro cell activity on silicon-doped vaterite/poly (lactic acid) composites. Acta Biomater. 2009;5:57-62. doi:10.1016/j.actbio.2008.08.004

24. Wang T, Qian S, Zha GC, et al. Synergistic effects of titania nanotubes and silicon to enhance the osteogenic activity. Colloids Surf B Biointerfaces. 2018;171:419-426. doi:10.1016/j.colsurfb.2018.07.052

25. Zhao X, Wang T, Qian S, Liu X, Sun J, Li B. Silicon-doped titanium dioxide nanotubes promoted bone formation on titanium implants. Int J Mol Sci. 2016;17:292. doi:10.3390/ijms17030292

26. Zhang W, Jin Y, Qian S, et al. Vacuum extraction enhances rhPDGFBB immobilization on nanotubes to improve implant osseointegration in ovariectomized rats. Nanomed.-Nanotechnol. 2014;10:1809-1818. doi:10.1016/j.nano.2014.07.002

27. Han Y, Chen D, Sun J, Zhang Y, Xu K. UV-enhanced bioactivity and cell response of micro-arc oxidized titania coatings. Acta Biomater. 2008;4:1518-1529. doi:10.1016/j.actbio.2008.03.005
28. Yamamoto O, Alvarez K, Kashiwaya Y, Fukuda M. Surface characterization and biological response of carbon-coated oxygen-diffused titanium having different topographical surfaces. J Mater Sci-Mater M. 2011;22:977-987. doi:10.1007/s10856-011-4267-x

29. Minagar S, Berndt CC, Wang J, Ivanova E, Wen C. A review of the application of anodization for the fabrication of nanotubes on metal implant surfaces. Acta Biomater. 2012;8:2875-2888. doi:10.1016/j. actbio.2012.04.005

30. Torres-Costa V, Martinez-Munoz G, Sanchez-Vaquero V, et al. Engineering of silicon surfaces at the micro- and nanoscales for cell adhesion and migration control. Int J Nanomed. 2012;7:623-630. doi:10.2147/IJN.S27745

31. Low SP, Williams KA, Canham LT, Voelcker NH. Evaluation of mammalian cell adhesion on surface-modified porous silicon. Biomaterials. 2006;27:43464538. doi:10.1016/j.biomaterials.2006.04.015

32. Qian S, Liu XY, Ding CX. Effect of Si-incorporation on hydrophilicity and bioactivity of titania film. Surf Coat Technol. 2013;229:156161. doi:10.1016/j.surfcoat.2012.07.048

33. Anselme K, Ponche A, Bigerelle M. Relative influence of surface topography and surface chemistry on cell response to bone implant materials. Part 2: biological aspects. $P \quad I$ Mech Eng $H$. 2010;224:1487-1507. doi:10.1243/09544119JEIM901

34. Friguglietti J, Das S, Le P, et al. Novel silicon titanium diboride micropatterned substrates for cellular patterning. Biomaterials. 2020;244:119927. doi:10.1016/j.biomaterials.2020.119927

35. Premnath P, Tan B, Venkatakrishnan K. Programming cell fate on bio-functionalized silicon. Colloids Surf $B$ Biointerfaces. 2015;128:100-105. doi:10.1016/j.colsurfb.2015.02.013

36. Abazari MF, Hosseini Z, Zare Karizi S, et al. Different osteogenic differentiation potential of mesenchymal stem cells on three different polymeric substrates. Gene. 2020;740:144534. doi:10.1016/j.gene.20 20.144534

37. Wang Z, Wang X, Tian Y, et al. Degradation and osteogenic induction of a $\mathrm{SrHPO}_{4}$-coated $\mathrm{Mg}-\mathrm{Nd}-\mathrm{Zn}$ - Zr alloy intramedullary nail in a rat femoral shaft fracture model. Biomaterials. 2020;247:119962. doi:10.1016/j.biomaterials.2020.119962

38. Wang B, Sun JY, Qian S, et al. Adhesion of osteoblast-like cell on silicon-doped $\mathrm{TiO}_{2}$ film prepared by cathodic arc deposition. Biotechnol Lett. 2013;35:975-982. doi:10.1007/s10529-013-1155-0

39. Wang B, Sun J, Qian S, et al. Proliferation and differentiation of osteoblastic cells on silicon-doped $\mathrm{TiO}_{2}$ film deposited by cathodic arc. Biomed Pharmacoth. 2012;66:633-641. doi:10.1016/j.biopha.20 12.08 .008

40. Zhang Z, Sun J, Hu H, Wang Q, Liu X. Osteoblast-like cell adhesion on porous silicon-incorporated $\mathrm{TiO}_{2}$ coating prepared by micro-arc oxidation. J Biomed Mater Res B. 2011;97:224-234. doi:10.1002/ jbm.b.31804

41. Murai K, Takeshita F, Ayukawa Y, Kiyoshima T, Suetsugu T, Tanaka T. Light and electron microscopic studies of bone-titanium interface in the tibiae of young and mature rats. J Biomed Mater Res. 1996;30:523-533. doi:10.1002/(SICI)1097-4636(199604)30:4<523:: AID-JBM11>3.0.CO;2-I

42. Rico H, Gallego-Lago JL, Hernandez ER, et al. Effect of silicon supplement on osteopenia induced by ovariectomy in rats. Calcified Tissue Int. 2000;66:53-55. doi:10.1007/s002230050010 


\section{Publish your work in this journal}

The International Journal of Nanomedicine is an international, peerreviewed journal focusing on the application of nanotechnology in diagnostics, therapeutics, and drug delivery systems throughout the biomedical field. This journal is indexed on PubMed Central, MedLine, CAS, SciSearch ${ }^{\mathbb{B}}$, Current Contents ${ }^{\mathbb{B}} /$ Clinical Medicine, $^{2}$
Journal Citation Reports/Science Edition, EMBase, Scopus and the Elsevier Bibliographic databases. The manuscript management system is completely online and includes a very quick and fair peer-review system, which is all easy to use. Visit http://www.dovepress.com/ testimonials.php to read real quotes from published authors. 